\title{
Intraocular production of a cytokine (CINC) responsible for neutrophil infiltration in endotoxin induced uveitis
}

\author{
Yan Guex-Crosier, Arthur JWittwer, Francois G Roberge
}

\begin{abstract}
Aims/background-The subcutaneous injection of bacterial endotoxin in Lewis rats produces an acute intraocular inflammation evolving over a 24 hour period. This endotoxin induced uveitis (EIU) is characterised by a biphasic protein exudation and a cellular infiltrate composed of macrophages and polymorphonuclear neutrophils (PMNs). This model was used to study the mechanism of cellular infiltration in ocular inflammation.

Methods-EIU was induced by a subcutaneous injection of lipopolysaccharide (LPS) (S typhimurium) at $350 \mu \mathrm{g} / \mathrm{kg}$. The levels of cytokine induced neutrophil chemoattractant (CINC) were measured every 2 hours in the serum and in the aqueous humour by ELISA. The intraocular inflammation was quantified by protein measurement and leucocyte counting.
\end{abstract}

Results-The kinetics of CINC production in the systemic circulation showed a rapid rise, peaking 2 hours after LPS injection, followed by a progressive decline over the next 8 hours. In the eye, the CINC levels increased above the serum levels 10 hours after EIU induction corresponding to the time of cellular infiltration. When leucocyte entry in the eye was inhibited by $56 \%$ and $64 \%$ with an antiadhesion molecule antibody, there was only a slight reduction in the aqueous humour CINC levels of $9 \%$ and $16 \%$, respectively, indicating that CINC was produced by ocular tissue cells. The specific effect of CINC in the eye was confirmed when a direct intraocular injection of $250 \mathrm{ng}$ of purified CINC was followed by significant PMN infiltration, in the absence of protein exudation.

Conclusion-The data indicate that the production of the CINC chemotactic factor by ocular tissue participates in the inflammatory reaction in EIU.

(Br f Ophthalmol 1996;80:649-653)

Gonin Hospital,

Ophthalmology Service,

University of Lausanne,

Lausanne, Switzerland.

Correspondence to: $\mathrm{Dr}$ Francois G Roberge, National Institutes of Health, Bldg 10, Room 10 N 202, 10 Center Dr MSC 1858,

Bethesda, MD, 20892-1858, USA.

Accepted for publication 11 March 1996 ins have been implicated in liver and kidney failure, as well as in adult respiratory distress syndrome. ${ }^{1}$ The biological activity of endotoxins has been attributed to the lipid A moiety of cell wall lipopolysaccharide (LPS). ${ }^{2}$ The best studied effect of endotoxin is the induction of cardiovascular shock. Experimental studies ety of pathophysiological disorders. Endotox- uncovered a cascade of inflammatory cytokines mediating the vascular collapse. Tumour necrosis factor $\alpha$ (TNF- $\alpha$ ) and interleukin $1 \beta$ (IL-1 $\beta$ ) play a critical role in triggering this reaction. ${ }^{3}$ Other mediators, including IL-6, IL-8, lipid derivatives such as prostaglandin $\mathrm{E}_{2}$ (PGE2), leukotriene B4, and platelet activating factors (PAF), are also involved..$^{47}$ Several cell types participate in this response, with the macrophage and the vascular endothelial cells playing a central role. ${ }^{4}$

An intraocular inflammation termed endotoxin induced uveitis (EIU) is also caused by a systemic injection of endotoxin..$^{8-12}$ EIU sensitive strains include Lewis rats, $\mathrm{C} 3 \mathrm{H} / \mathrm{HeN}$ mice, and albino rabbits. The ocular disease in rats is characterised by an early progressive protein exudation within 2-4 hours after LPS injection, followed by a cellular infiltration starting 6-10 hours later and accompanied by a surge in protein entry into the eye. The inflammation is maximal at 24 hours, and lasts approximately 48 hours. The main infiltrating cell types are the polymorphonuclear neutrophils (PMNs) and the monocytes. ${ }^{813}$ An advantage of this model is that it allows for a separate analysis of the inflammatory mechanism inside the eye in parallel and in association with the intravascular compartment.

We used the EIU model to analyse the nature and kinetics of chemotactic cytokines involved in acute anterior uveitis. These chemokines constitute a family of factors regulating the traffic of leucocytes from the blood to peripheral tissues. This family is subdivided in the two subgroups CXC and CC according to the presence or absence of one amino acid between two shared conserved cysteine residues. ${ }^{15}$ This structural division corresponds to distinct roles. The CXC family mainly attracts PMN leucocytes, and the CC family is active on lymphocytes and monocytes. IL-8 is one of the best known member of the CXC family. IL-8 is produced by numerous inflammatory and organ specific cells. ${ }^{15}$ In rodents, the function of IL-8 appears to be accomplished by cytokine induced neutrophil chemoattractant (CINC). CINC is an $8 \mathrm{kDa}$ peptide of the CXC family with a $70 \%-72 \%$ structural homology to the human GRO factors. ${ }^{15-17}$ Functionally, CINC shares more similarity with IL-8. However, contrary to IL-8 which can attract both PMNs and T lymphocytes, CINC chemotaxis is restricted to PMN cells. ${ }^{17}{ }^{18}$ Like IL-8, the secretion of CINC is 
induced by LPS and by various cytokines such as IL-1 $\beta$ and TNF- $\alpha$. $^{17}$

We report a study of the dynamics of intraocular CINC production in relation to its intravascular levels, and the role of this cytokine in the mechanism of EIU.

\section{Materials and methods}

\section{INDUCTION OF OCULAR INFLAMMATION}

EIU was induced in male Lewis rats weighing 250 to $275 \mathrm{~g}$ (Charles River, Raleigh, NC, USA) by a subcutaneous injection of Salmonella typhimurium LPS (Lot No 10720JA, Difco Laboratories, Detroit, MI, USA) at 350 $\mu \mathrm{g} / \mathrm{kg}$ in $0.1 \mathrm{ml}$ phosphate buffered saline (PBS). At the indicated time points, serum and aqueous humour were collected after euthanasia by carbon dioxide inhalation. The aqueous humour of the two eyes of each rat were pooled, and $1 \mu \mathrm{l}$ was placed on a silanated glass slide (Digene, Beltsville, MD, USA) and allowed to dry at room temperature. The cells were counted under a microscope after staining with $0.4 \%$ Trypan blue solution under a cover slip. The remaining aqueous humour was centrifuged at $10000 \mathrm{~g}$ to remove the cells and the protein content was measured by the Coomassie colorimetric assay (Pierce, Rockford, IL, USA) in duplicate in microtitre plates, by reference to an albumin standard. CINC levels were measured as indicated below.

INHIBITION OF INTRAOCULAR CELL INFILTRATION WITH ANTIADHESION MOLECULE ANTIBODY

In some experiments, the cellular infiltration into the eye was inhibited by an intraperitoneal injection of $2.0 \mathrm{mg}$ per rat of the antibody $(\mathrm{Ab})$ $1 B 6$ (generous gift of Dr K Sokolowski, RepliGen Corporation, Cambridge, MA, USA) 4 hours after LPS administration. $1 \mathrm{~B} 6$ is a mouse antirat monoclonal $\mathrm{Ab}$ blocking cellular adhesion through the CD11b chain of the Mac-1 adhesion molecule. $1 \mathrm{~B} 6$ is an $\mathrm{IgG}_{1}$ and does not produce complement cell lysis. The aqueous humour was collected 16 hours after LPS injection for cell counting and measurement of the CINC level.

\section{INTRAOCULAR CINC INJECTION}

The rats were anaesthetised with sodium pentobarbitone injected intraperitoneally at 50 mg/kg (Anpro Pharmaceutical, Arcadia, CA, USA) and with topical application on the eye of proxymetacaine hydrochloride (proparacaine hydrochloride) $0.5 \%$ (Alcon Inc, $\mathrm{Hu}$ macao, Puerto Rico). The anterior chamber was opened through a corneal stab incision with a $15^{\circ}$ Alcon ophthalmic knife and partially drained of aqueous humour. Synthetic CINC peptide, certified to be free of LPS by Peptide International (Louisville, KY, USA) was injected at $250 \mathrm{ng}$ in $10 \mu \mathrm{l}$ PBS in one eye with a glass micropipette. The contralateral eye received PBS alone. The aqueous humour was collected 4 hours later for protein measurement and cell count (optimal time determined by preliminary clinical observations of the anterior chamber at $1,2,3,4,6$, and $8 \mathrm{~h}$ after injection).
SERUM AND AQUEOUS HUMOUR CINC MEASUREMENT

CINC levels were measured by sandwich enzyme linked immunosorbent assay (ELISA) as described previously. ${ }^{19}$ Briefly, Immulon-1 plates (Dynatech Laboratories Inc, Chantilly, VA, USA) were coated overnight at $4^{\circ} \mathrm{C}$ with an affinity purified goat anti-CINC Ab (7 $\mu \mathrm{g} / \mathrm{ml}, 100 \mu \mathrm{l} /$ well) diluted in $0.1 \mathrm{M}$ bicarbonate buffer $\mathrm{pH}$ 9.6. Additional binding sites were blocked by a 2 hour incubation at $37^{\circ} \mathrm{C}$ with $5 \%$ milk in $50 \mathrm{mM}$ TRIS- $\mathrm{HCl}$ normal saline $+0.05 \%$ Tween-20 (TBS-T) buffer $\mathrm{pH}$ 7.5. Dilutions of serum and aqueous humour samples in TBS-T $(100 \mu \mathrm{l} /$ well $)$ were incubated for 2 hours at $22^{\circ} \mathrm{C}$. A standard curve was constructed with purified CINC (Peptide International, Louisville, KY, USA) at a concentration range of 20.00 to $0.35 \mathrm{ng} / \mathrm{ml}$. Captured CINC was reacted with rabbit anti-CINC (Peptide International) at 1:20 000 for 2 hours at $22^{\circ} \mathrm{C}$, followed by alkaline phosphatase labelled goat anti-rabbit IgG for 45 minutes. The reaction was developed with the Gibco BRL ELISA amplification system (Gibco BRL, Gaithersburg, MD, USA).
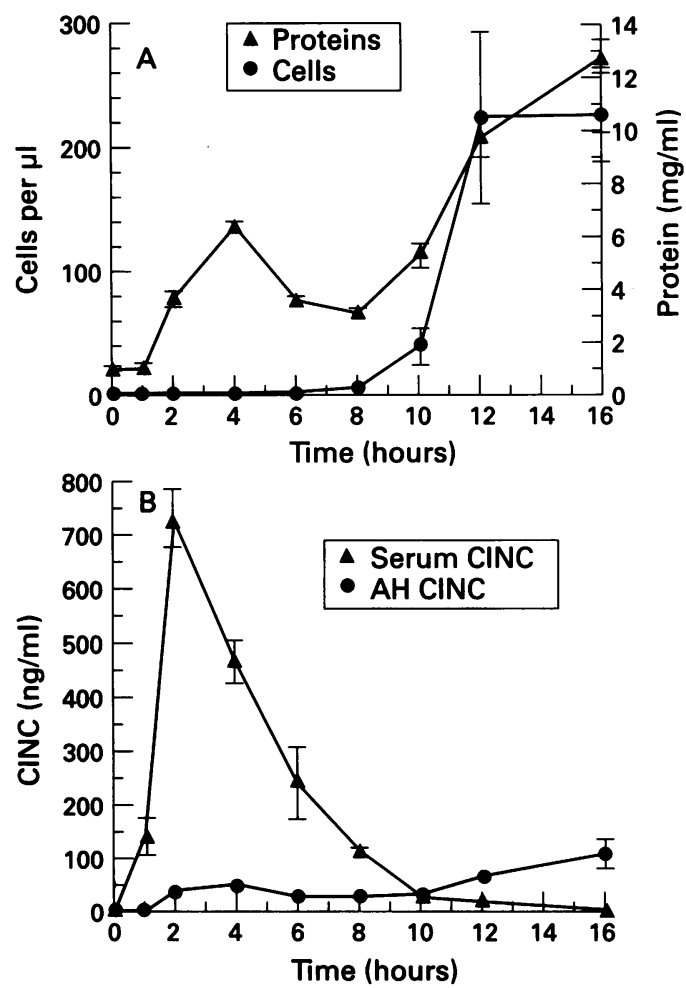

Figure 1 (A)Kinetics of protein exudation and cellular infiltration in the eye after subcutaneous lipopolysaccharide (LPS) injection (350 $\mathrm{\mu g} / \mathrm{kg})$. Each time point represents five animals. The protein concentration was measured by Coomassie blue microassay. The number of leucocytes per $\mu l$ was counted after drying and staining with trypan blue. The protein exudation followed a biphasic curve with the highest peak approximately synchronous with the cellular infiltration. (B) Serum and aqueous humour ( $A H)$ samples were collected at $0,1,2,4,6,8,10,12$, and 16 hours after subcutaneous LPS injection. Cytokine induced neutrophil chemoattractant (CINC) levels were measured by sandwich ELISA, with reference to a standard curve of purified CINC. Each time point represents the average (SEM) of measurements from five animals. An intraocular positive gradient of CINC is observed 10 hours after LPS injection. 

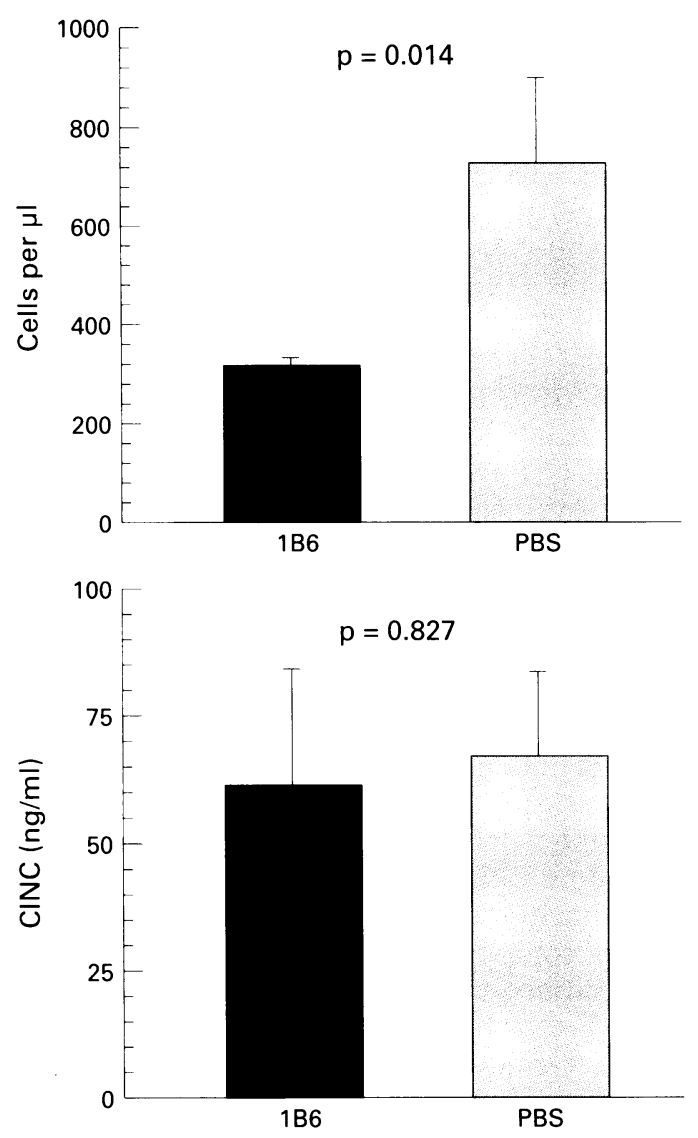

Figure 2 Rats were injected subcutaneously with lipopolysaccharide (LPS) and treated 4 hours later with $2 \mathrm{mg}$ of the $1 \mathrm{B6}$ anti-CD11b/CD18 (Mac-1) Ab, or phosphate buffered saline (PBS) vehicle control, injected intraperitoneally. The aqueous humour was collected 16 hours after LPS injection, and the CINC levels measured as above in relation to the number of infiltrating leucocytes. $A$ marked decrease in cellular infiltration was associated with only a slight decrease in CINC levels in the aqueous humour of the anti-Mac-1 antibody treated rats.

\section{STATISTICAL ANALYSIS}

The unpaired Student's $t$ test was used for the comparison of means of protein or CINC levels between groups, and the paired $t$ test was used for the comparison of measurements between eyes injected with CINC and the contralateral control eyes. The cell counts between different groups of rats were compared with the Mann-Whitney rank sum test. Differences were considered significant at a $\mathrm{p}$ value $\leqslant 0.05$. The calculations were done with the STATVIEW

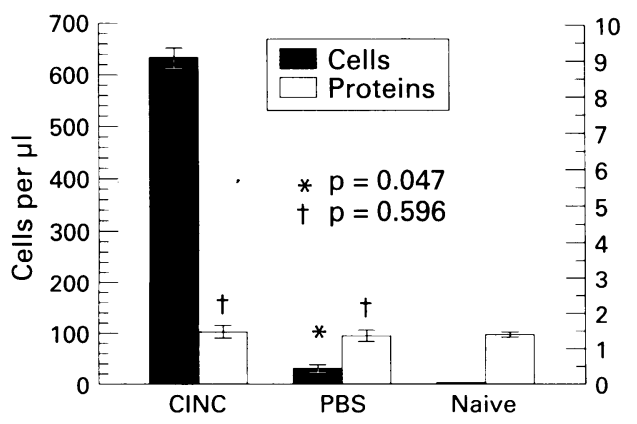

Figure 3 Intraocular injection of CINC (250 $\mathrm{ng}$ in $10 \mu \mathrm{l}$ $P B S$ ) induced an important cellular infiltration of the eye in comparison with the contralateral eye injected with PBS alone. CINC did not induce protein exudation in the aqueous humour.
V.4.01 software for Macintosh (Abacus Concepts Inc, Berkeley, CA, USA).

\section{Results}

KINETICS OF INTRAOCULAR INFLAMMATION

AFTER LPS INJECTION

Protein leakage was detected in the anterior chamber of the eye 2 hours after subcutaneous LPS injection. The kinetics of the exudation are shown in Figure 1A. The protein level rises early to a peak at 4 hours followed by a slow decrease broken by a sharp surge beginning between 8 and 10 hours after LPS. Cells were first observed in the eye at the 10 hour time point, and their number increased rapidly between 10 and 12 hours (Fig 1A).

KINETICS OF SERUM AND OCULAR CINC LEVELS In the serum, the level of CINC peaked 2 hours after LPS injection with a mean concentration of 734 (SEM 54) ng/ml, and decreased progressively during the following 8 hours (Fig $1 B$ ). In the aqueous humour CINC was detected 2 hours after LPS injection, and started to increase above the serum level at 10 hours (Fig 1B). The increase of CINC concentration in the aqueous humour above the serum levels, in the later time points, corresponded to the time of entry of leucocytes into the anterior chamber of the eye (Table 1).

\section{Production of CINC in the eye}

In order to differentiate if the CINC measured in the eye was produced locally and attracted the leucocytes, or was secreted by the infiltrating cells themselves, we inhibited the cellular infiltration and assessed its effect on the intraocular CINC levels. Inhibiting leucocyte adhesion by treating the animals with 1B6 caused a $56 \%$ reduction in cellular infiltration of the eye with 321 (12) cells/ $\mu$ l compared with 730 (155) cells $/ \mu \mathrm{l}$ in the control group $(p=0.014)$ (Fig 2). However the aqueous humour CINC level in these 1B6 treated rats decreased by only $9 \%$ compared with the control treated rats $(p=0.827)($ Fig 2$)$. In a second experiment the $1 \mathrm{~B} 6$ treatment produced a $64 \%$ reduction in cells infiltration accompanied by only a $16 \%$ decrease in intraocular CINC levels compared with the controls.

Table 1 Correlation of the positive cytokine induced neutrophil chemoattractant (CINC) gradient towards the anterior chamber with leucocyte infiltration. Lewis rats were injected subcutaneously with lipopolysaccharide at 350 $\mu \mathrm{g} / \mathrm{kg}$. Serum and aqueous humour were collected at the indicated time points

\begin{tabular}{lcc}
\hline $\begin{array}{l}\text { Time points } \\
(h)\end{array}$ & $\begin{array}{l}\text { CINC gradient } \\
\text { towards the eye } \\
(\mathrm{ng} / \mathrm{ml})\end{array}$ & $\begin{array}{l}\text { Aqueous humour } \\
\text { cells } \\
(\text { cells/ } \mu l)\end{array}$ \\
\hline 0 & $0(0)$ & $0(0)$ \\
1 & $-145(34)$ & $0(0)$ \\
2 & $-694(62)$ & $0(0)$ \\
4 & $-413(46)$ & $1(1)$ \\
6 & $-213(74)$ & $2(2)$ \\
8 & $-85(10)$ & $6(1)$ \\
10 & $6(8)$ & $40(15)$ \\
12 & $46(7)$ & $226(70)$ \\
16 & $104(28)$ & $228(38)$ \\
\hline
\end{tabular}

* CINC was measured in the serum and in the aqueous humour by ELISA, and a gradient representing the intraocular level minus the serum level was determined. Each time point represents the average (SEM) of measurements from five animals. 
Injection of CINC in the eye

The chemotactic effect of a direct intraocular injection of CINC was evaluated. When CINC was injected in the anterior chamber of the eye of naive rats there was a significant influx of cells into the aqueous humour. By Giemsa stain the cells were almost exclusively PMNs (not shown). The mean cell count in the CINC injected eyes $(n=5)$ was of $630(213)$ cells $/ \mu 1$ compared with 31 (8) cells $/ \mu \mathrm{l}$ in the eye injected with PBS alone $(p=0.047)$ (Fig 3). CINC had no effect on protein exudation. The mean protein concentration was of $1.46(0.17)$ $\mathrm{mg} / \mathrm{ml}$ in the CINC injected eyes and 1.36 $(0.16) \mathrm{mg} / \mathrm{ml}$ in the control eyes $(\mathrm{p}=0.59)$ (Fig 3). In naive non-injected rats, the mean protein concentration was $1.41(0.08) \mathrm{mg} / \mathrm{ml}$.

\section{Discussion}

The study of animal models of endotoxic shock and the injection of low doses of endotoxin in human volunteers helped understand the inflammatory cascade triggered by LPS. ${ }^{20}{ }^{21}$ In the blood, the LPS molecule attaches to a carrier protein (LBP), and in this complex form interacts with the CD14 cell surface receptor to activate monocyte. ${ }^{22}{ }^{23}$ TNF- $\alpha$ and IL-1 $\beta$ are released, causing a cardiovascular shock. $^{2024}{ }^{25}$ TNF- $\alpha$ can be detected in circulation half an hour after LPS injection and the level peaks 30 minutes later. ${ }^{24}{ }^{26-28}$ IL-1 $\beta$ appears shortly after TNF- $\alpha$ and has a synergistic effect on the production of other inflammatory cytokines such as IL-6 and IL-8. ${ }^{24}{ }^{25}$ The circulating array of cytokines induced by LPS is probably responsible for the early rupture of the blood-aqueous barrier that we observed in EIU. During the early phase of EIU, the passive entry of the inflammatory cytokines TNF- $\alpha$ and IL-1 from the circulation probably induces the intraocular production of factors such as CINC by ocular tissue cells. Indeed the messenger RNA of several cytokines has been detected in the eye in EIU. ${ }^{29}$ The intraocular injection of TNF- $\alpha$ was shown to induce IL- 6 production in the eye. ${ }^{30}$ In addition, ocular specific cells in culture were able to produce inflammatory mediators. ${ }^{31-33} \mathrm{~A}$ large population of immunocompetent cells such as resident macrophages and dendritic cells was also observed in the eye. ${ }^{34-36}$ In our observations the small amount of CINC found in the eye up to 8 hours after LPS injection appears to come from the circulation with the protein exudate. At this time the gradient of CINC is directed towards the intravascular compartment and cells are not infiltrating the eye. Cellular infiltration of the anterior chamber occurs approximately 10 hours after LPS, when the CINC gradient is favouring the eye. This later increase in CINC presumably comes from ocular cell synthesis, because at this time the serum levels are lower than in the eye. In addition, these CINC levels are only slightly affected when leucocyte infiltration is reduced by anti-adhesion molecule $\mathrm{Ab}$ treatment. The reported in vitro chemotactic dose-response curve of CINC increases from $0.8 \mathrm{ng} / \mathrm{ml}$ to a maximum at $250 \mathrm{ng} / \mathrm{ml}$ with a half maximum level of $8 \mathrm{ng} / \mathrm{ml} .^{37}$ The CINC gradient level of 6 to $104 \mathrm{ng} / \mathrm{ml}$ that we measured in the eye correlates well with these doses. We also confirmed the chemotactic effect of CINC in the eye by direct intraocular injection. The observed effect was purely chemotactic for $P M N$ leucocytes and did not induce any protein infiltration. In EIU, the activation of circulating leucocytes by LPS certainly increases the ability of the cells to enter the eye. However, the activation of PMNs was not necessary for the cells to migrate in the eye in response to the tested dose of CINC. One of the contributing factors of ocular infiltration in EIU is the induction of adhesion molecules on the leucocytes and the vascular endothelium induced by LPS. ${ }^{38}$ In humans the CD11/CD18 adhesion molecule on PMN cells is upregulated by IL-8. ${ }^{39}$ The high levels of CINC in the blood of rats may play a similar role contributing to the priming of leucocytes for ocular infiltration. The shifting of the chemotactic gradient towards the eye as seen here with CINC during the course of EIU may occur with other chemotactic molecules. The use of the EIU model to study these chemotactic gradients should help to unravel the sequence of events leading to ocular infiltration in uveitis. Yan Guex-Crosier was supported by a grant from the Swiss
National Fund for young Researchers and from the Sociéte National Fund for young Researchers and from

We would like to thank Dr Karen Sokolowski and Dr Marc We would like to thank Dr Karen Sokolowski and Dr Marc
Bree from RepliGen Corporation for providing the $1 \mathrm{~B} 6$ antibody and Dr Terrence Knisely for his helpful suggestions.

1 Martin MA, Silverman HJ. Gram-negative sepsis and the adult respiratory distress syndrome. Clin Infect Dis 1992;14:1213-28.

2 Bayston KF. Bacterial endotoxin and current concepts in the diagnosis and treatment of endotoxaemia. 7 Med Microbiol 1990;31:73-83.

3 Fischer E, Van Zee KJ, Marano MA, Rock CS, Kenney JS, Poutsiaka DD, et al. Interleukin-1 receptor antagonist in experimental inflammation and in human disease. Blood 1992;79:196-200.

4 Dinarello CA, Gelfand JA, Wolff SM. Anticytokine strategies in the treatment of the systemic inflammatory response gies in the treatment of the systemic in
syndrome. $\Im A M A 1993 ; 269: 1829-35$.

5 Kuhns DB, Alvord G, Gallin JI. Increased circulating cytokines, cytokine antagonists, and E-selectin after intravenous administration of endotoxin in humans. $\mathcal{F}$ Infect Dis 1995;171:145-52.

6 Fong Y, Moldawer LL, Marano M, Wei H, Tatter SB, Clarick RH, et al. Endotoxinemia elicits increased circulating B2-IFN/IL-6 in man. F Immunol 1989;142:2321-4.

7 Bozza PT, Castro-Faria-Neto HC, Silva AR, Larangeira AP, Silva PMR, Martins MA, et al. Lipopolysaccharideinduced pleural neutrophil accumulation depends on marrow neutrophils and platelet activating factor. Eur $\mathcal{f}$ Pharmacol 1993;270:143-9.

8 Rosenbaum JT, McDevitt HO, Guss RB, Egbert PR. Endotoxin-induced uveitis in rats as a model for human Endotoxin-induced uveitis in rats

9 Ayo C. A toxic ocular reaction. I. New property of Ayo C. A toxic ocular reaction. I. New prope
Schwartzman toxins. $f$ Immunol 1942;46:113-25.

10 Ayo C. A toxic ocular reaction. II. On the nature of the reaction. F Immunol 1942;46:127-32.

11 Herbort CP, Okumura A, Mochizuki M. Endotoxininduced uveitis in the rat: a study of the role of inflammation mediators. Graefes Arch Klin Exp Ophthalmol 1988;226: 553-8.

12 Hoekzema R, Verhagen C, van Haren M, Kijlstra A. Endotoxin-induced uveitis in the rat. Invest Ophthalmol Vis Sci 1992;33:532-9.

13 Cousins SW, Guss RB, Howes EJ, Rosenbaum JT. Endotoxin-induced uveitis in the rat: observations on altered vascular permeability, clinical findings, and histology. Exp Eye Res 1984;39:65-76.

$14 \mathrm{Kim} \mathrm{MK}$, Palestine AG, Nussenblatt RB, Chan CC. Expression of class II antigen in endotoxin induced uveitis. Curr Eye Res 1986;5:869-76.

15 Baggiolini M, Dewald B, Moser B. Interleukin-8 and related chemotactic cytokines-CXC and CC chemokines. Adv

16 Zagorski J, DeLarco JE. Rat CINC (cytokine-induced neutrophil chemoattractant) is the homolog of the human trophil chemoattractant) is the homolog of the human
GRO proteins but is encoded by a single gene. Biochem GRO proteins but is encoded by a singl
Biophys Res Commun 1993;190:104-10. 
17 Watanabe K, Kinoshita S, Nakagawa H. Purification and characterization of cytokine-induced neutrophil chemoatcharacterization of cytokine-induced neutrophil chemoattractant produced by epithelioid cell line of normal rat kidney NRK-52E

18 Hirasawa N, Watanabe M, Mue S, Watanabe K, Tsurufuji S, Ohuchi $\mathrm{K}$. Induction of neutrophil infiltration by rat chemotactic cytokine (CINC) and its inhibition by dexamethasone in rats. Inflammation 1992;16:187-96. 19 Wittwer AJ, Carr LS, Zagorski J, Dolecki GJ, Crippes BA, phil chemoattractant (CINC) by a metastatic rat cell line: purification and production of blocking antibodies. $₹ \mathrm{Cell}$ Physiol 1993;156:421-7.

20 Michie HR, Manogue KR, Spriggs DR, Revhaug A O'Dwyer S, Dinarello CA, et al. Detection of circulating tumor necrosis factor after endotoxin administration. $N$ Engl f Med 1988;318:1481-6.

21 Martich DG, Danner RL, Ceska M, Suffredini AF. Detection of interleukin-8 and tumor necrosis factor in Detection of interleukin-8 and tumor necrosis factor in normal humans after intravenous endotoxin: the effect

anti-inflammatory agents. $\mathcal{F}$ Exp Med $1991 ; 173: 1021-4$.
Wright SD, Ramos RA, Tobias PS, Ulevitch RJ, Mathison C. CD14, a receptor for complexes of lipopolysaccharide (LPS) and LPS binding protein. Science 1990;249:1431-3.

23 Haziot A, Tsuberi B-Z, Goyert SM. Neutrophil CD14: biochemical properties and role in the secretion of tumo necrosis factor- $\alpha$ in response to lipopolysaccharide. $\mathcal{f}$ Immunol 1993;150:5556-65.

24 Van Zee KJ, DeFroge LE, Fischer E, Marano MA, Kenney JS, Remick DG, et al. IL-8 in septic shock, endotoxinemia, and after IL-1 administration. $\mathcal{F}$ Immunol 1991;146:347882 .

25 de Vos AF, van Haren MAC, Verhagen C, Hoekzema $R$ Kijlstra A. Kinetics of intraocular tumor necrosis factor and interleukin- 6 in endotoxin-induced uveitis in the rat. Invest Ophthalmol Vis Sci 1994;35:1100-6.

26 Jongeneel VC. Regulation of TNF $\alpha$ gene. In: Lewin J, van Deventer SJH, van der Poll T, Sturk A, ed. Bacterial endotoxin. Basic science to anti-sepsis strategies. New York: Alan R Liss, 1994:367-81.

27 Wakabayashi G, Gelfand JA, Burke JF, Thompson RC, Dinarello CA. A specific receptor antagonist for interleukin 1 prevents Escherichia coli-induced shock in rabbits. FASEB ๆ 1991;5:338-43.

28 Beutler B, Grau GE. Tumor necrosis factor in the pathogenesis of infectious diseases. Crit Care Med 1993;21: 423-35.
29 de Vos AF, Klaren VNA, Kijlstra A. Expression of multiple cytokines and IL-1RA in the uvea and retina during
endotoxin-induced uveitis in the rat. Invest Ophthalmol Vis Sci 1994;35:3873-83.

30 de Vos A, van Haren M, Verhangen C, Hoekzema R, Kijlstra A. Tumour necrosis factor-induced uveitis in the Lewis rat is associated with intraocular interleukin-6 production. Exp Eye Res 1995;197-207.

31 Roberge FG, Caspi RC, Nussenblatt RB. Glial retina Muller cells produce II -1 activity and have a dual effect on autoimmune T helper lymphocytes. Antigen presentation manifested after removal of suppressive activity. $\mathcal{F}$ Immunol 1988;140:2193-6. 32 Helbig H, Kittredge KL, Gurley RC, Thurau SR, Palestine
AG, Nussenblatt RB. Endotoxin-induced production of inflammatory mediators by cultured ciliary epithelial cells. Curr Eye Res 1990;9:501-5.

33 de Kozak Y, Naud MC, Bellot J, Faure JP, Hicks D. Differential tumor necrosis factor expression by resident retinal cells from experimental uveitis-susceptible and -resistant rat strains. $\mathcal{f}$ Neuroimmunol 1994;55:1-9.

34 McMenamin PG, Holthouse I, Holt PG. Class II major histocompatibility complex (Ia) antigen-bearing dendritic cells within the iris and ciliary body of the rat eye: distribution, phenotype and relation to retinal microglia. Immunology 1992;77:385-93.

35 McMenamin PG, Crewe J, Morrison S, Holt PG. Immunomorphologic studies of macrophages and MHC class II-positive dendritic cells in the iris and ciliary body of the rat, mouse, and human eye. Invest Ophthalmol Vis Sci 1994 35:234-50.

36 Forrester JV, McMenamin PG, Liversidge J, Lumsden L. Dendritic cells and dendritic macrophages in the uveal tract. Adv Exp Med Biol 1993;329:599-604.

37 Nakagawa $\mathrm{H}$, Ikesue $A$, Kato $\mathrm{H}$, Debuchi $\mathrm{H}$, Watanabe $\mathrm{K}$ Tsurufuji S, et al. Changes in the levels of rat interleukin T/CINC and gelatinase in the exudate of carrageenin8/CINC and gelatinase in the exudate of carrageenin-
induced inflammation in rats. $\mathcal{F}$ Pharmacobiodyn 1992;15: induced

38 Whitcup SM, DeBarge LR, Rosen H, Nussenblatt RB Chan C-C. Monoclonal antibody against CD11b/CD18 inhibits endotoxin-induced uveitis. Invest Ophthalmol Vis Sci 1993;34:673-81.

39 Detmers PA, Lo SK, Olsen EE, Walz A, Baggiolini M, Cohn ZA. Neutrophil-activating protein 1 /interleukin 8 stimulates the binding activity of the leukocyte adhesion receptor CD11b/CD18 on human neutrophils. F Exp Med 1990; 171:1155-62. 